"This material may be downloaded for personal use only. Any other use requires prior permission of the American Society of Civil Engineers. This material may be found at [https://ascelibrary.org/doi/10.1061/9780784414422.ch01]." 
CHAPTER 1

\title{
Green Technologies for Sustainable Water Management: Introduction and Overview
}

\author{
Huu Hao Ngo, Wenshan Guo, Zhuo Chen, Rao Y. Surampalli and \\ Tian C. Zhang
}

\subsection{Introduction}

Climate change, rapid development and population growth of many nations and the consequent rapid rise in levels of water consumption and contamination have raised concerns about the unsustainability of current water use patterns and supply systems. Specifically, the world population continues to expand with a growth rate of $1.2 \%$ each year, resulting in increased pressure on water quality, safety and health. Although the global amount of water is generally considered to be sufficient for the current population from the perspective of the total hydrologic cycle, world water resources are concentrated in certain areas, and severe water shortages are emerging in other places (Pimentel and Pimentel 2008). In addition to water deficits, improperly managed freshwater resource systems have triggered considerable water pollution. The problems are even worse in developing countries as they discharge approximately $90-95 \%$ of their untreated urban sewage directly into surface waters without rigorous water regulations (Pimentel et al. 2012). Therefore, to alleviate these existing situations, the awareness of environmental responsibilities should be strengthened (Tseng et al. 2013).

The concept of sustainable water management generally involves the improvement of the health of surface water and groundwater systems, avoidance of over-extraction of freshwater supplies, identification of alternative water resources (e.g., rainwater, stormwater, desalinated water and recycled water), and implementation of environmental related policies and educational campaigns (NWC 2011). Faced with many challenges, the use of green technologies that encourage efficient forms of recycling and reuse is encouraged in the water industry. These include various innovations on water collection, treatment, distribution and drainage systems as well as enhanced approaches to management, assessment strategies, policies and regulations. After being successfully implemented, they can play crucial 
roles in enhancing sustainability, driving green growth and achieving a balance between economic, social and environmental factors while maintaining productivity, prosperity and efficiency (ATSE 2012).

This chapter presents the background, current development and future opportunities of green technologies and issues to facilitate the strategic planning of sustainable water management systems. The chapter is structured as follows: the first section deals with fundamental concepts and demand analysis; the following section describes in detail the current and future applications of green technologies for sustainability improvement in water management; and the third section overviews the core ideas and key findings from each book chapter. The chapter concludes by discussing the appropriate approaches and policies in achieving sustainability objectives and promoting green design and supplies for water utilization.

\section{$1.2 \quad$ Fundamentals}

\subsubsection{Concepts and Need Analysis of Sustainable Water Management}

Achieving sustainable solutions to today's environmental problems requires long-term planning and actions. Sustainable management generally incorporates environmental, economic, social, and energy and resource sustainability (Dincer and Rosen 2005). Figure 1.1 outlined these four essential factors impacting sustainable development and their interdependencies. Resource issues are particularly prevalent at present, and water management appears to provide one component of an effective sustainable solution. Specifically, the sustainable water management approach is to view all water systems as a whole, including drinking water, wastewater, rainwater, and stormwater drainage as a collective system that should be managed together to be truly efficient and sustainable, namely, integrated water management. In this approach, all water systems are looked upon as a positive resource in the environment with multiple supplies for use in many cases (Struck 2012).

Sustainable water management approaches have been increasingly applied to explore and analyze existing and future water-related issues, as well as to support water managers and decision-makers to put forward solutions for potential problems. They are of great necessity and importance as mismanagement is likely to impose significant constraints on exploitation and development and to affect the performance of water resource systems, including their effects on future water availability, water demand and water management strategies (Dong et al. 2013). The specific advantages of sustainable water management are presented as follows:

- Solving problems. Some water-related problems such as drought, flooding, groundwater over-extraction, water-borne diseases, land and water degradation, insufficient wastewater treatment, on-going damage to ecosystems, and escalating water conflicts in rural areas that might be intractable to conventional, singlesector approaches can be addressed by sustainable water management approaches. 
As such, issues could be identified holistically and solved effectively from multiple sectors without creating other troubles and complications.

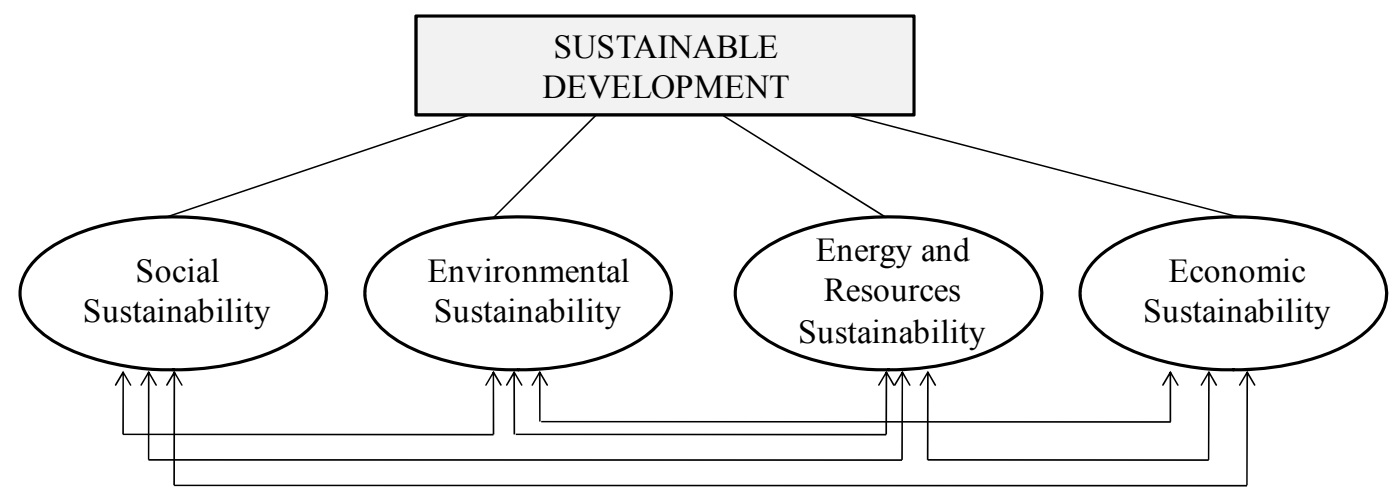

Figure 1.1. Factors affecting sustainable development and their interdependences (modified from Midilli et al. 2006)

- Avoiding poor investments and expensive mistakes. Decision-making based on short-term, segmented view would be rarely effective in the long-haul and can trigger unsustainable gains, unforeseen consequences and lost opportunities. Worse still, it is often the environment that has been sacrificed, together with negative consequences for both social and economic development. Comparatively, sustainable water management promotes the consideration of economic implications of infrastructure maintenance, water services and potential for costrecovery, and both short- and long-term environmental impacts. This can avoid the losses and high costs associated with unsustainable development and irreparable harms.

- Getting the most value from investments in infrastructure. Sustainable water management can ensure maximum returns on investments from infrastructure planning, design and management both socially and economically. It facilitates the different investments working synergistically and producing greater returns than possible through a single-sector approach.

- Allocating water strategically. Sustainable water management can provide strong links among allocation decisions, national development and economic planning processes, using tools such as water pricing and tariffs, appropriate incentives and subsidies, and the removal of ill-considered incentives and subsidies both inside and outside the water sector. This could significantly contribute to the improvement of water use efficiency (GWP 2004).

To achieve sustainability, it involves the continuous reconciliation of water demand by the human environment with water supply by the natural system. Thus, depending on specific problems, it may also requires the consideration of land and water management, evapotranspiration, water quality and quantity, upstream and downstream water uses, and all stakeholders in the planning and management 
processes (GWP 2000). The uncertainties associated with climate, demographic, economic, social, technical and political conditions also need to consider. However, instead of trying to be comprehensive, the optimal water management should mainly focus on the key components and relationships accounting for the greatest variability in the system behavior. This would allow decision makers and water authorities to consider multiple factors and to deal with the complexity and interconnections within and between natural and human environments (Liu et al. 2008).

\subsubsection{Concepts and Need Analysis of Green Technologies}

Green technologies are technologies creating products and facilities that can improve economic productivity, conserve natural resources and limit adverse impacts on the environment and social wellbeing (Environmental Leader 2013). The concept of green technologies can be applied to the water management field to support the growth of new industries (e.g., new end uses of recycled water), bring technological innovations (e.g., state-of-the-art water treatment approaches) to water market and position the country to capture green growth opportunities. While the application of green technology could greatly harness economic opportunities by promoting productivity, prosperity and living standards, the strategies and innovations can also balance the other environmental, social and technical aspects, which would underpin sustainable water management into the future (ATSE 2012).

There is an urgent need to exploit and develop appropriate green technologies that promote design, production and supply chain because the major cause of water shortage and continued deterioration of the global environment is the unsustainable and unregulated pattern of consumption and production (Tseng et al. 2013). The limitations on the amount of freshwater consumption that can be taken from natural sources such as groundwater and surface water have forced the industry to expand the supplementary sources of water such as rainwater, stormwater, desalinated water and/or recycled water, which in most cases need extensive treatment before usage for health and environmental safety reasons. Apart from environmental drivers associated with water scarcity issues, to control water quality, many governments promote effluent discharge regulations and encourage the use of best available technologies to limit the allowable concentrations of certain contaminants in waste streams. Additionally, highly purified water is increasingly needed in industries (e.g., energy industry) that require technological solutions to fulfill their water needs (Frost and Sullivan 2010). For instance, the recycled water used as boiler's make-up water should be of very high quality, especially when the boiler is operated under high pressure. As wastewater containing impurities may lead to boiler corrosion, deposits, sludge formation, scaling, fouling and foaming, advanced treatment processes such as ultrafiltration (UF), reverse osmosis (RO), or ion exchange are often required. Likewise, only high-quality water can be adopted in electronics, food processing, chemical and pharmaceutical industries (U.S. EPA 2004; Chen et al. 2013). 
To develop green technologies strategically, a comprehensive framework for managing water resources and prioritizing investment decisions is needed. Figure 1.2 shows the procedures and major considerations involved in the establishment of a full assessment framework. It consists of four phases, where phase 1 is the primary screening step to identify the prospects of new green technologies. To verify the feasibility of proposed technologies, Phase 2 starts with the consideration of particular evaluation criteria from five identified categories, including environmental, social, technical, economic and commercial aspects, and then applies the qualitative or quantitative approach for making a trade-off among different factors. Furthermore, phase 3 is to implement fit-for-purpose policies on green growth principles and shared responsibilities according to the analysis results. Finally, phase 4 is the management step that includes the communication, review and reporting so as to achieve community-wide acceptance and satisfying outcomes for water sustainability.

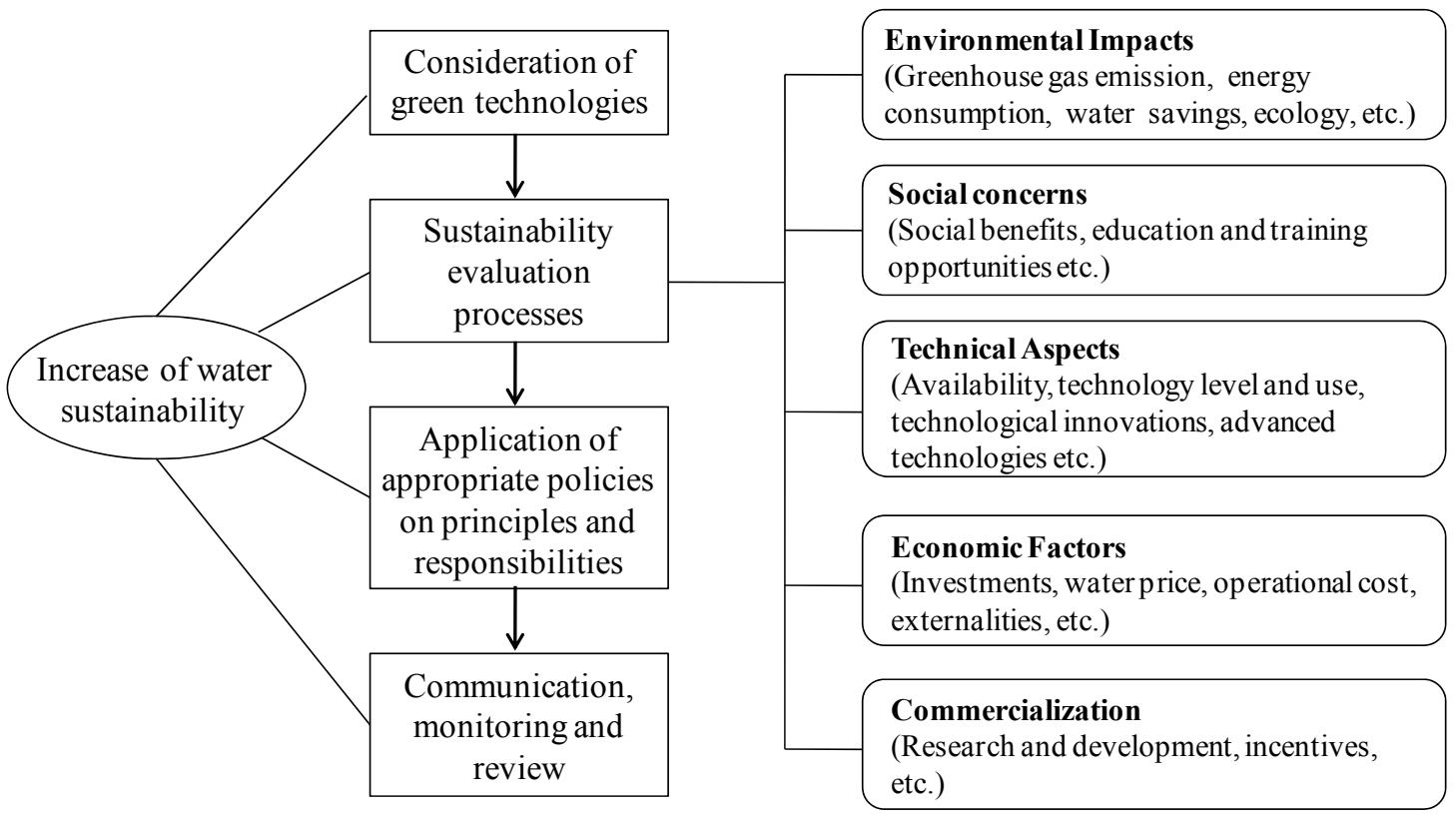

Figure 1.2. The comprehensive framework in the development of green technologies for sustainable water management (modified from Dincer and Rosen 2005)

\subsection{Current Status and Future Perspectives}

\subsubsection{Current Status, Key Drivers and Restraints}

With respect to water collection and supply systems, water balance analysis becomes essential, as it determines the relationship between storage capacity, reuse demand, and reliability of supply. Particularly, the designs should be effective not only at the full capacity level, but also in reduced-service scenarios such as under non-optimal, supply-limited and unforeseen conditions. However, the over-reliance 
of supply-driven urban water supplies has been increasingly discovered and criticized, which are regarded as wasteful and expensive supply-side solutions. Thus, demand management should be implemented with a focus on measures that make better and efficient use of limited supplies. The specific definition of demand management is the adaptation and implementation of a strategy (policies and initiatives) by a water institution influencing water demand and water usage to meet objectives (such as economic efficiency, social development, social equity, environmental protection and political acceptability) so as to achieve sustainability of water supply and services (Vairavamoorthy et al. 2008). Table 1.1 lists a series of green technology opportunities proposed for different water resources under the demand management methodology. They are assessed across multiple green-growth and sustainability indicators covering environmental, economic and social impacts via a qualitative approach. Notably, a rigorous quantitative approach (e.g., cost-effectiveness analysis, triple-bottom-line analysis or multi-criteria analysis) should be utilized for a complete evaluation (ATSE 2012).

In terms of water treatment, as each source of water has its own characteristics and constituents, it requires different treatment levels and technologies for certain use purposes. For example, high pathogenic levels in water are likely to trigger health and environmental risks while chemical composition (e.g., ammonia, calcium, magnesium, silica and iron) may cause corrosion of pipes and machinery, scale formation, foaming, etc. Besides, physical parameters such as suspended solids, sand and grit can lead to solids deposition, fouling and blockages, whereas excessive nutrients may result in slime formation and microbial growth (DEC 2006). Thus, it is indispensable to understand all kinds of water sources and their characteristics for fitfor-purpose treatment and applications. A detailed discussion on specific green technologies for different water resources is presented as follows. As readilyavailable surface, ground and rain water require only minimal treatment, they are not discussed in detail.

Rainwater/stormwater. Rainwater generally has very good water quality even though it does contain some particulate matter from dust particles from the air. The level of total dissolved solids varies from region to region but is typically between 2 and $20 \mathrm{mg} / \mathrm{l}$ (Brown et al. 2005). The water quality of collected rainwater depends significantly on the surface from which the water is collected (Table 1.2). Stormwater typically contains material mobilized in its path of flow including litter, dust and soil, fertilizers and other nutrients, chemicals and pesticides, microorganisms, metals, oils and grease, and thus, needs better management for non-point source pollution. However, management practices are different in different countries. For example, in the U.S., regulations for Municipal Separate Storm Sewer System (MS4) belongs to the Clean Water Act. A sector (e.g., a state's department of transportation) is required to manage its runoff pollution within its MS4 boundaries, such as 1) capture/treat the first 0.5 inches Water Quality Volume (WQV) that runs off of any new/redeveloped impervious area; and 2) implement 6 minimum Best Management Practices (BMPs) to reduce stormwater pollutant effluents to the 
Maximum Extent Practicable (MEP). However, so far, there is no water quality criterion linked with numeric limits.

Table 1.2. Water quality of harvested rainwater from various surfaces

\begin{tabular}{lllllll}
\hline Sample & $\mathbf{p H}$ & $\begin{array}{l}\text { Turbidity } \\
(\mathbf{N T U})\end{array}$ & $\begin{array}{l}\text { Conductivity } \\
(\boldsymbol{\mu S S i e m e n s )}\end{array}$ & $\begin{array}{l}\text { Hardness } \\
\left(\mathbf{p p m} \mathbf{C a C O}_{3}\right)\end{array}$ & $\begin{array}{l}\text { TSS } \\
(\mathbf{p p m})\end{array}$ & $\begin{array}{l}\text { Coliform } \\
(\mathbf{C F U} / \mathbf{m L})\end{array}$ \\
\hline Metal Roof & 5.97 & 1.3 & 12.4 & 0.5 & 3 & 100 \\
Plumbing & 6.89 & 0.5 & 17.1 & 6 & 6 & $>500$ \\
Cistern & 8.91 & 2.4 & 735 & 10 & 9 & 3 \\
Tap Water & 7.32 & 0.3 & 77.1 & 24 & 2 & 0 \\
Shingle Roof & 5.94 & 8.3 & 455 & 41 & 6 & $>500$ \\
EWEB Range & $7.5-7.8$ & $0.02-0.04$ & $45-65$ & $18-25$ & $<0.5$ & 0 \\
\hline
\end{tabular}

Reference: Matt and Cohen (2001).

Table 1.3. Stormwater quality criteria for public health risk management in Australia

\begin{tabular}{llll}
\hline $\begin{array}{l}\text { Water } \\
\text { indicators }\end{array}$ & \multicolumn{2}{l}{ Water quality criteria ${ }^{1}$} & Level 3 \\
\cline { 2 - 4 } E. coli & $<1 \mathrm{cfu} / 100 \mathrm{~mL}$ & $<10 \mathrm{cfu} / 100 \mathrm{~mL}$ & $<1000 \mathrm{cfu} / 100 \mathrm{~mL}$ \\
Turbidity & $\leq 2 \mathrm{NTU}$ & $\leq 2 \mathrm{NTU}$ & - \\
$\mathrm{pH}$ & $6.5-8.5$ & $6.5-8.5$ & $6.5-8.5$ \\
$\mathrm{Cl}_{2}$ residual & $\begin{array}{l}1 \mathrm{mg} / \mathrm{L} \text { after } 30 \mathrm{mins} \\
\text { or equivalent level of } \\
\text { pathogen reduction }\end{array}$ & $\begin{array}{l}1 \mathrm{mg} / \mathrm{L} \text { after } 30 \text { mins or } \\
\text { equivalent level of } \\
\text { pathogen reduction }\end{array}$ & - \\
& &
\end{tabular}

$\begin{array}{llll}\text { Applications } & \begin{array}{l}\text { Reticulated non- } \\ \text { potable residential } \\ \text { uses (e.g., garden } \\ \text { watering, toilet } \\ \text { flushing and car } \\ \text { washing) }\end{array} & \begin{array}{l}\text { Spray or drip irrigation of } \\ \text { open spaces, parks and } \\ \text { sports grounds (no access } \\ \text { controls) }\end{array} & \begin{array}{l}\text { Spray or drip irrigation } \\ \text { (controlled access) or } \\ \text { subsurface irrigation of } \\ \text { open spaces, parks and } \\ \text { sports grounds }\end{array} \\ & \begin{array}{l}\text { Industrial uses: dust } \\ \text { suppression, construction, } \\ \text { site use (human exposure } \\ \text { possible) }\end{array} & \begin{array}{l}\text { Industrial uses: dust } \\ \text { suppression, construction, } \\ \text { site use, process water (no } \\ \text { human exposure) }\end{array} \\ & \begin{array}{l}\text { Ornamental water bodies } \\ \text { (no access controls) } \\ \text { Fire-fighting }\end{array} & \begin{array}{l}\text { Ornamental water bodies } \\ \text { (access controls) }\end{array} \\ & & \end{array}$

Specific Salt, nutrients, heavy Suspended solids, nutrient level:

concerns for metals, pesticides $\quad \mathrm{TP}^{2}(\mathrm{mg} / \mathrm{L})$ : 0.05 (long term); 0.8-12 (short term); $\mathrm{TN}^{3}$

applications (mg/L): 5 (long term); 25-125 (short term)

${ }^{1}$ Values are median for Escherichia coli, 24-hour median for turbidity and 90th percentile for $\mathrm{pH}$;

${ }^{2}$ Total phosphorus; ${ }^{3}$ Total nitrogen. Reference: DEC (2006). 
Table 1.1. Green technology opportunities for different water resources collection and supply

\begin{tabular}{|c|c|c|c|c|c|c|}
\hline \multirow{2}{*}{$\begin{array}{l}\text { Water } \\
\text { resources } \\
\text { collection and } \\
\text { supply }\end{array}$} & \multirow[t]{2}{*}{ Green technology opportunities } & \multicolumn{5}{|c|}{ Water sustainability indicator } \\
\hline & & $\begin{array}{l}\text { Lower } \\
\text { energy \& } \\
\text { resource } \\
\text { demand }\end{array}$ & $\begin{array}{l}\text { Reduce } \\
\text { waste \& } \\
\text { pollutant }\end{array}$ & $\begin{array}{l}\text { Increase } \\
\text { economic } \\
\text { efficiency }\end{array}$ & $\begin{array}{l}\text { Conserve } \\
\text { natural } \\
\text { assets }\end{array}$ & $\begin{array}{l}\text { Promote } \\
\text { social } \\
\text { cohesion }\end{array}$ \\
\hline \multirow[t]{4}{*}{ Surface water } & $\begin{array}{l}\text { - Improve understanding of surface water- } \\
\text { groundwater connectivity and hydrological } \\
\text { modeling }\end{array}$ & $\sqrt{ }$ & & & $\sqrt{ }$ & \\
\hline & $\begin{array}{l}\text { - Measure soil moisture in real-time for efficient } \\
\text { water application in irrigation }\end{array}$ & $\sqrt{ }$ & $\sqrt{ }$ & $\sqrt{ }$ & $\sqrt{ }$ & \\
\hline & - Control water conveyance systems in real time & $\sqrt{ }$ & $\sqrt{ }$ & $\sqrt{ }$ & & \\
\hline & $\begin{array}{l}\text { - Intermittent water supply by physically cutting } \\
\text { off the supply and limiting the consumers' } \\
\text { ability }\end{array}$ & $\sqrt{ }$ & $\sqrt{ }$ & & $\sqrt{ }$ & \\
\hline \multirow[t]{4}{*}{ Groundwater } & - Ensure extraction is sustainable over time & $\sqrt{ }$ & & $\sqrt{ }$ & $\sqrt{ }$ & \\
\hline & $\begin{array}{l}\text { - Expand managed aquifer recharge, storage and } \\
\text { reuse }\end{array}$ & & $\sqrt{ }$ & $\sqrt{ }$ & $\sqrt{ }$ & \\
\hline & - Install low-energy high-efficiency pumping & $\sqrt{ }$ & & $\sqrt{ }$ & & \\
\hline & $\begin{array}{l}\text { - Recover energy through mini-and micro- } \\
\text { hydroelectric generation }\end{array}$ & $\sqrt{ }$ & & $\sqrt{ }$ & & \\
\hline \multirow[t]{3}{*}{ Rainwater } & $\begin{array}{l}\text { - Install tanks in areas with suitable rainfall } \\
\text { patterns }\end{array}$ & & & & $\sqrt{ }$ & \\
\hline & $\begin{array}{l}\text { Consider monolayer-based evaporation } \\
\text { mitigation systems for reservoirs }\end{array}$ & & & $\sqrt{ }$ & & \\
\hline & $\begin{array}{l}\text { - Improve climate and rainfall predictions and } \\
\text { projections over multiple time scales }\end{array}$ & & & $\sqrt{ }$ & & $\sqrt{ }$ \\
\hline \multirow[t]{2}{*}{ Stormwater } & - Harvest stormwater (online or offline) & & $\sqrt{ }$ & & $\sqrt{ }$ & $\sqrt{ }$ \\
\hline & - Reduce leakage from water assets & $\sqrt{ }$ & $\sqrt{ }$ & $\sqrt{ }$ & & \\
\hline \multirow[t]{2}{*}{$\begin{array}{l}\text { Recycled } \\
\text { water }\end{array}$} & $\begin{array}{l}\text { - Recycle wastewater when there is a positive } \\
\text { business care }\end{array}$ & & $\sqrt{ }$ & $\sqrt{ }$ & & \\
\hline & $\begin{array}{l}\text { - Deploy satellite and airborne sensors for early } \\
\text { detection of water pollution }\end{array}$ & & $\sqrt{ }$ & & & \\
\hline
\end{tabular}


However, a treatment system for rainwater/stormwater harvesting and reuse needs to consider both stormwater quality criteria and treatment techniques to meet the end-use requirements and minimize public health and environmental risks. According to Table 1.3, the main aspects of water quality relevant to public health considerations specified in Australian guidelines are Escherichia coli concentration, turbidity, $\mathrm{pH}$ and chlorine residual. Escherichia coli is an important microbial quality indicator whereas turbidity and $\mathrm{pH}$ are important chemical indicators that may affect the efficiency of chlorine disinfection. However, specific stormwater quality criteria should be applied when considering the site-specific conditions of catchment areas (e.g., catchments with industrial land uses or significant sewer overflows) and different end-uses (e.g., residential uses, irrigation, industrial uses and aquifer storage and recovery) (DEC 2006; Asano et al. 2007).

As can be seen in Table 1.4, stormwater treatment measures can be generally grouped into three categories: primary, secondary and tertiary (CSIRO 2006; Begum et al. 2008; Blecken et al. 2010). The physical screening or rapid sedimentation techniques in the primary stage are mainly to retain gross pollutants and coarse sediments. Comparatively, secondary treatment involves applications of finer particle sedimentation and filtration techniques to remove fine particles and attached pollutants. Additionally, tertiary treatment aims to mitigate nutrients and heavy metal concentrations (Begum et al. 2008). For some schemes that require further pathogen removal, disinfection (e.g., UV light, chlorination or ozonation) and/or advanced treatment techniques (e.g., membrane filtration) should be employed at the end of the treatment train. While technologies designed for general stormwater pollution control are frequently utilized, more innovative technologies designed specifically for stormwater recycling together with new assessment technologies should be exploited to guarantee the necessary reliability of treatment and reuse. Several studies have retrofitted the conventional biofilters by introducing a submerged (partly anoxic) zone with an embedded carbon source. With this advanced technique, total nitrogen removal has been enhanced significantly due to improved denitrification (Dietz et al. 2006; Zinger et al. 2013). Li et al. (2012) further indicated that this approach could eliminate adverse effects of drying weather conditions on E. coli removal and achieve the recommended water quality for secondary contact recreational water use in relation to E. coli. Blecken et al. (2009) showed that the modified biofilter also exhibited positive impact on metal treatment, especially on the copper $(\mathrm{Cu})$ removal. The presence of submerged zone and carbon source allows the outflow $\mathrm{Cu}$ concentrations to meet Swedish and Australian water quality guidelines.

Desalinated water. Desalinated water is relatively expensive to produce. Therefore, its efficient management from the inception of the water cycle at treatment plants to the reuse of treated effluent is of paramount importance. Figure 1.3 depicts management approaches to develop in terms of operational, technological and research aspects of desalinated water treatment and reuse. The RO membrane system is by far the dominant technology used primarily due to its lower cost in comparison to other technologies. To further reduce the cost of RO technology, modifications of the traditional RO process are being increasingly considered and employed, including 
i) the blending of existing technologies (e.g., multiple-effect distillation, multi-stage flash, and vapor compression) or innovative technologies (e.g., forward osmosis, membrane distillation, adsorption desalination, and microbial desalination cells), and ii) process optimization (e.g., more efficient pretrement, longer lasting membranes, more energy efficient pumps) (Zhang et al. 2012). The key drivers and prospective green technological developments in desalination plant treatment processes include:

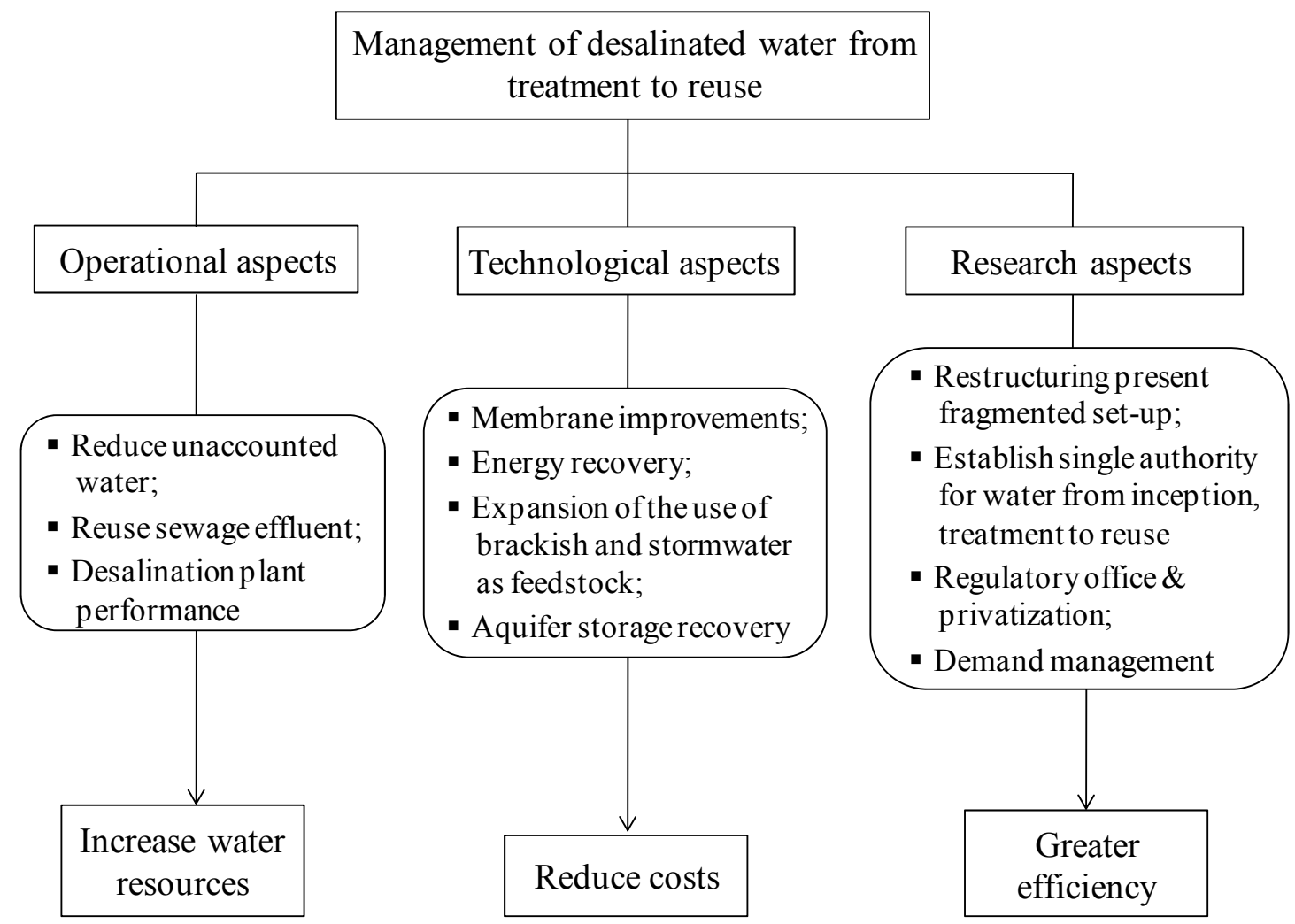

Figure 1.3. Elements of desalinated water management from treatment to reuse (modified from Dabbagh 2001) 
Table 1.4. Stormwater treatment approaches and corresponding performances

\begin{tabular}{|c|c|c|c|c|c|c|c|c|c|c|c|}
\hline \multirow[b]{2}{*}{$\begin{array}{l}\text { Stormwater treatment } \\
\text { techniques }\end{array}$} & \multirow{2}{*}{$\begin{array}{l}\text { Catch. } \\
\text { area } \\
\text { (ha) }\end{array}$} & \multicolumn{6}{|c|}{ Pollutant trapping efficiency } & \multirow[b]{2}{*}{$\begin{array}{l}\text { Cleaning } \\
\text { frequencies }\end{array}$} & \multirow[b]{2}{*}{$\begin{array}{l}\text { Head } \\
\text { needs }\end{array}$} & \multirow[b]{2}{*}{$\begin{array}{l}\text { Initial } \\
\text { costs }\end{array}$} & \multirow{2}{*}{$\begin{array}{l}\mathrm{O} \& \\
\mathrm{M} \\
\text { costs }\end{array}$} \\
\hline & & Gross & $\begin{array}{l}\text { Coarse } \\
\text { sed. }\end{array}$ & $\begin{array}{l}\text { Med. } \\
\text { sed. }\end{array}$ & $\begin{array}{l}\text { Fine } \\
\text { sed. }\end{array}$ & Att. & Diss. & & & & \\
\hline \multicolumn{12}{|c|}{ Primary treatment approaches } \\
\hline Baffled pits & $0.1-2$ & $\mathrm{~L}$ & M & $\mathrm{L} / \mathrm{M}$ & $\mathrm{L}$ & $\mathrm{N}$ & $\mathrm{N}$ & monthly & $\mathrm{L}$ & $\mathrm{L} / \mathrm{M}$ & $\mathrm{L} / \mathrm{M}$ \\
\hline Circular settling tanks & $1-20$ & $\mathrm{~L} / \mathrm{M}$ & $\mathrm{H}$ & $\mathrm{M} / \mathrm{H}$ & M & $\mathrm{L} / \mathrm{M}$ & $\mathrm{N}$ & monthly & $\mathrm{L}$ & $\mathrm{H}$ & M \\
\hline Circular screens & $5-150$ & $\mathrm{VH}$ & $\mathrm{H}$ & M & $\mathrm{L} / \mathrm{M}$ & $\mathrm{L}$ & $\mathrm{N}$ & quarterly & $\mathrm{L}$ & $\mathrm{H}$ & $\mathrm{M}$ \\
\hline Sediment settling basins & $10-500$ & $\mathrm{~N}$ & $\mathrm{M} / \mathrm{H}$ & M & $\mathrm{L}$ & $\mathrm{N} / \mathrm{L}$ & $\mathrm{N}$ & half-yearly & $\mathrm{L}$ & $\mathrm{L} / \mathrm{M}$ & $\mathrm{L} / \mathrm{M}$ \\
\hline Green gully & - & $\mathrm{H}$ & $\mathrm{L}$ & $\mathrm{L}$ & $\mathrm{L}$ & $\mathrm{N}$ & $\mathrm{N}$ & monthly & $\mathrm{L}$ & $\mathrm{L}$ & $\mathrm{L}$ \\
\hline \multicolumn{12}{|c|}{ Secondary treatment approaches } \\
\hline Grass swales & $0.1-5$ & $\mathrm{~L}$ & $\mathrm{M} / \mathrm{H}$ & $\mathrm{M}$ & $\mathrm{L} / \mathrm{M}$ & $\mathrm{L} / \mathrm{M}$ & $\mathrm{L}$ & - & $\mathrm{L}$ & $\mathrm{L}$ & $\mathrm{L}$ \\
\hline Infiltration trenches & $0.1-5$ & $\mathrm{~L}$ & $\mathrm{M} / \mathrm{H}$ & M & $\mathrm{L} / \mathrm{M}$ & $\mathrm{L} / \mathrm{M}$ & $\mathrm{L}$ & - & $\mathrm{L}$ & $\mathrm{L}$ & $\mathrm{M} / \mathrm{H}$ \\
\hline Infiltration basin & $10-100$ & $\mathrm{~N}$ & $\mathrm{M} / \mathrm{H}$ & M & M & M & $\mathrm{L}$ & - & $\mathrm{L}$ & $\mathrm{L} / \mathrm{M}$ & $\mathrm{H}$ \\
\hline $\begin{array}{l}\text { Extended detention } \\
\text { basins }\end{array}$ & $10-500$ & $\mathrm{~L}$ & $\mathrm{M} / \mathrm{H}$ & M & $\mathrm{L} / \mathrm{M}$ & $\mathrm{L} / \mathrm{M}$ & $\mathrm{L}$ & - & $\mathrm{L}$ & $\mathrm{L} / \mathrm{M}$ & $\mathrm{M} / \mathrm{H}$ \\
\hline Sand filters & $1-50$ & $\mathrm{~L}$ & $\mathrm{M} / \mathrm{H}$ & $\mathrm{M} / \mathrm{H}$ & M & M & $\mathrm{L}$ & - & $\mathrm{H}$ & $\mathrm{M} / \mathrm{H}$ & $\mathrm{M} / \mathrm{H}$ \\
\hline \multicolumn{12}{|c|}{ Tertiary treatment approaches } \\
\hline Constructed wetlands & $>10$ & $\mathrm{~L} / \mathrm{M}$ & $\mathrm{H}$ & $\mathrm{M} / \mathrm{H}$ & $\mathrm{L} / \mathrm{M}$ & $\mathrm{M} / \mathrm{H}$ & $\mathrm{L} / \mathrm{M}$ & $10-13 \mathrm{yrs}$ & $\mathrm{L} / \mathrm{M}$ & $\mathrm{H}$ & M \\
\hline Biofilters & - & $\mathrm{L} / \mathrm{M}$ & $\mathrm{H}$ & $\mathrm{M} / \mathrm{H}$ & $\mathrm{M} / \mathrm{H}$ & $\mathrm{M} / \mathrm{H}$ & $\mathrm{M} / \mathrm{H}$ & - & $\mathrm{L} / \mathrm{M}$ & $\mathrm{H}$ & $\mathrm{M}$ \\
\hline
\end{tabular}


1) Distillation processes, which cover: i) Scaling prevention techniques for film evaporation. Some existing technologies on the reduction of scaling on the Multistage Flash System (MSF) tube surfaces seem to lead to scale deposition being transferred into the flash chambers and causing blockage of the demisters. Apart from MSF, other thermal desalination technologies, such as multiple effect distillation (MED) with thermal vapor compression (TVC) and mechanical vapor compression (MVC) should be taken into account as well. They have become the most efficient distillation processes available in the market today in terms of energy consumption and water recovery ratio. As the systems are electrically driven, they are considered as clean and green processes with high reliability and simplicity for operation and maintenance. ii) Corrosion reduction. There is a need to develop alloys and other materials for moving and non-moving parts with corrosion resistance similar to those that have been recently developed but at more economical prices. iii) Computer modeling and capacity increase. The increase of plant capacity and utilization of modeling techniques to optimize the design, simulation, and operating conditions can provide desalinated water at a lower cost. iv) Heat transfer improvement. New alloys with higher heat transferability than those presently available could improve the efficiency of MSF drastically (Dabbagh 2001; DEP 2010).

2) Membrane processes, which cover: i) Membrane improvement. Disinfection of feed water prior to RO is essential to prevent biofouling of the membrane surfaces, which can inevitably lead to additional energy consumption and a loss of performance. Chlorine is by far one of the most cost-effective disinfection approaches for water treatment. However, since modern RO membranes are generally susceptible to chlorine damage, there is a demand for membrane improvement so as to tolerate biocidal concentrations of chlorine in continuous operation over several years. Graham-Rowe (2008) and Gunderson (2008) reported on newly developed nanocomposite membranes, which are thin-film composite membranes with the nanostructured material. When being applied, the benefits such as improved efficiency of extraction, reduced biofouling and maintenance costs by repelling impurities, reduced energy needs, and longer membrane life can be obtained. Alternatively, other biocides such as ozone may be advantageous in RO systems but have not been adequately studied. ii) Fouling and scaling mechanisms and control measures. A more fundamental understanding of fouling and scaling mechanisms and implementation of green control measures can result in lower operational cost and extended membrane life. The control measures include: fouling control by operating these membrane systems below critical flux, pretreatment of the feedwater, membrane backwashing and cleaning, and addition of carriers (e.g., zeolite, powdered activated carbon and sponge) (Ngo et al. 2013). iii) Seawater coagulation and filtration techniques. The removal of most organic suspended and colloidal matter in large seawater RO plants is usually carried out using conventional coagulation and filtration techniques. Thus, research into broader spectrum green coagulants might be of benefit and should be given more consideration. iv) Energy recovery devices. Improved efficiency in energy utilization could contribute to the reduction of desalination cost. Additionally, the use of alternative energy sources like 
waste heat, solar and/or geothermal can reduce the need for fossil fuel-based energy. For instance, energy-efficient pumps such as axial piston pressure exchanger pump and rotary-type energy-recovery device could not only lessen the costs but also improve the consistency of pressure (Gunderson 2008). v) Expansion of the use of brackish and stormwater as feedstock. Although seawater is the primary feedstock, brackish water and stormwater are potential starting materials for inland communities. vi) Aquifer storage recovery. The system involves the use of injection wells for underground storage of desalinated water in a suitable aquifer when the capacity of water supply facilities exceeds the demand, and its subsequent recovery from the same well to meet seasonal, peak, emergency or long-term demand. As this approach is low-cost, it can be developed to improve the use of water supply and water treatment facilities (Dabbagh 2001).

Table 1.5 presents some other recent innovations in desalination technologies. They are regarded as green approaches due to the reduced costs and lower adverse impacts to the environment. Additionally, co-location of desalination facilities at or near existing power plants or large municipal wastewater treatment plant (WWTP) can also substantially reduce the carbon footprints, environmental impacts and capital and/or operational costs through the use of existing intake and outfall structures and the blending of desalination brine and power plant heated effluents (DEP 2010).

Recycled water. To ensure safe and reliable water reuse, green technologies that require less non-renewable energy sources, higher level of energy and nutrient recovery, reduced consumption of hazardous chemicals and enhanced removal of contaminants should be given more attention in the WWTP design and operation (Lofrano 2012).

Table 1.5. Recent green innovations in desalination technologies.

\begin{tabular}{|c|c|c|c|}
\hline $\begin{array}{l}\text { Desalination } \\
\text { technology }\end{array}$ & Key principles & $\begin{array}{l}\text { Recent } \\
\text { innovations }\end{array}$ & Advantages \\
\hline $\begin{array}{l}\text { Forward } \\
\text { osmosis }\end{array}$ & $\begin{array}{l}\text { 1. Use a high concentration } \\
\text { of a chemical to draw the } \\
\text { water molecules through } \\
\text { the membrane, leaving salts } \\
\text { behind; } \\
\text { 2. Separate the chemical } \\
\text { from water by heating; } \\
\text { 3. Reuse the chemical in } \\
\text { process }\end{array}$ & $\begin{array}{l}\text { 1. New } \\
\text { chemical } \\
\text { compounds to } \\
\text { drive process; } \\
\text { 2. New } \\
\text { membrane; } \\
\text { 3. Use waste } \\
\text { heat to drive the } \\
\text { separation }\end{array}$ & $\begin{array}{l}\text { 1. Lower energy } \\
\text { usage; } \\
\text { 2. High feed water } \\
\text { recovery; } \\
\text { 3. Reduced brine } \\
\text { discharge }\end{array}$ \\
\hline $\begin{array}{l}\text { Clathrate } \\
\text { desalination }\end{array}$ & $\begin{array}{l}\text { 1. Trap water molecules in } \\
\text { carbon dioxide molecules; } \\
\text { 2. Pressure water molecules } \\
\text { into a Clathrate crystal; } \\
\text { 3. Break down the crystal } \\
\text { to release the water } \\
\text { molecules }\end{array}$ & $\begin{array}{l}\text { 1. Increase the } \\
\text { size of the } \\
\text { crystal; } \\
\text { 2. Reduce the } \\
\text { energy demand }\end{array}$ & $\begin{array}{l}\text { 1. Operates at low } \\
\text { pressures; } \\
\text { 2. Suitable for all } \\
\text { qualities of water } \\
\text { sources }\end{array}$ \\
\hline Dewvaporation & $\begin{array}{l}\text { 1. Humidify a stream of } \\
\text { heated air by running a }\end{array}$ & $\begin{array}{l}\text { Newer energy } \\
\text { sources such as }\end{array}$ & $\begin{array}{l}\text { 1. Energy efficient - } \\
\text { uses recycled energy; }\end{array}$ \\
\hline
\end{tabular}




\begin{tabular}{|c|c|c|c|}
\hline & $\begin{array}{l}\text { stream of saline water on a } \\
\text { heated surface; } \\
2 \text {. Collect the condensate as } \\
\text { product water when the } \\
\text { saturated air is moved } \\
\text { along condensing heat } \\
\text { transfer films }\end{array}$ & $\begin{array}{l}\text { waste heat } \\
\text { and/or solar }\end{array}$ & $\begin{array}{l}\text { 2. Inexpensive to } \\
\text { manufacture; } \\
\text { 3. Passive-lower } \\
\text { O\&M; } \\
\text { 4. Suitable for all } \\
\text { qualities of water } \\
\text { sources }\end{array}$ \\
\hline $\begin{array}{l}\text { Freeze } \\
\text { desalination }\end{array}$ & $\begin{array}{l}\text { 1. Use the phase shift of } \\
\text { water from liquid to solid } \\
\text { to exclude the salt from the } \\
\text { ice crystals; } \\
\text { 2. Melt the crystals to } \\
\text { produce freshwater }\end{array}$ & $\begin{array}{l}\text { 1. Washing of } \\
\text { salts; } \\
\text { 2. Use of } \\
\text { density } \\
\text { gradients }\end{array}$ & $\begin{array}{l}\text { 1. Improved energy } \\
\text { efficiency compared } \\
\text { to distillation } \\
\text { processes; } \\
\text { 2. Minimal potential } \\
\text { for corrosion; } \\
\text { 3. Little scaling or } \\
\text { precipitation }\end{array}$ \\
\hline
\end{tabular}

1) Fit-for-purpose treatment. The adoption of fit-for-purpose treatment methods allows the prioritized identification of hazards and enables the targeted pollutants to be removed efficiently and cost-effectively. As for greywater, it includes water from household kitchen sinks, dishwashers, showers, baths, hand basins, and laundry, but excludes any input from toilets. Hence, compared with municipal and industrial sources, it is less polluted and low in contaminating pathogens, nitrogen, suspended solids and turbidity. Regarding the current treatment methods, physical (e.g., coarse sand, soil filtration, microfiltration (MF), and UF) and chemical (e.g., coagulation, photocatalytic oxidation, ion exchange and granular activated carbon) treatments are suitable to treat low strength greywater (e.g., laundry and showering wastewaters) for either restricted or unrestricted non-potable uses under safe conditions. These treatment technologies are widely used in small-scale residences, which are able to reduce $30-35 \%$ of freshwater consumption. While for medium and high-strength greywater (e.g., kitchen wastewater), additional biological treatment processes such as sequencing batch reactor (SBR), constructed wetland $(\mathrm{CW})$, or membrane bioreactor (MBR) are often used to remove biodegradable organic substances (Chen et al. 2013). The applications of treated greywater include toilet flushing, garden irrigation, recreational impoundments watering and clothes washing (Zhang et al. 2012).

Municipal wastewater often contains a broad spectrum of contaminants such as organic matters, pathogens and inorganic particles, which can be potential risks to human health and the environment. Particularly, some inorganic chemical pollutants (e.g., sodium, potassium, calcium, chloride, bromide, and trace heavy metals) are of concern in agricultural and landscape irrigation, as highly saline irrigation water can severely degrade the soil and the accumulation of heavy metals in soil can pose threats to the food chain. Furthermore, when considering the recycled water for potable reuse schemes, the trace organic pollutants such as pharmaceutical active compounds (PhACs) and endocrine disrupting compounds (EDCs) are important parameters that are likely to trigger adverse biological effects to health at part per trillion concentrations (Weber et al. 2006; Bhandari et al. 2009). Besides, from 
microbiological aspects, the main pollution groups are excreted organisms and pathogens from human and animal origins, where enteric viruses and protozoan pathogens are significantly more infectious than other bacterial pathogens. In terms of treatment approaches, membrane filtration has received considerable attention as it is capable of removing not only suspended solids and organic compounds but also inorganic contaminants such as heavy metals in wastewater through physical means. Depending on the pore size of the semi-permeable membrane, membrane technologies include MF, UF, nanofiltration (NF), and RO. MF membranes have the largest pore size $(0.05-2 \mu \mathrm{m})$ and typically reject suspended particles, colloids, and bacteria. UF $(<0.1 \mu \mathrm{m})$ and NF $(2 \mathrm{~nm})$ membranes have smaller pores, which can remove natural organic matter/soluble macromolecules and dissociated acids/sugars/pharmaceuticals/divalent ions, respectively. RO membranes $(0.1 \mathrm{~nm})$ are effectively nonporous and retain even many low molar mass solutes as water permeates through the membrane (ASTM 2010).

Comparatively, the composition of industrial wastewater varies considerably owing to different industrial activities. Even within a single type of industry, specific processes and chemicals used to produce similar products can differ, which leads to significant changes in wastewater characteristics over time. Generally, wastewaters from food processing industries (e.g., potato, olive oil, and meat processing) are contaminated with high levels of biological oxygen demand (BOD), chemical oxygen demand (COD), oil and grease, total suspended solids (TSS), nitrogen, and phosphorous. By contrast, industrial wastewaters (e.g., chemical and pharmaceutical producing, paper, textile, tannery, and metal working and refinery wastewaters) might be rich in heavy metals (e.g., $\mathrm{Cd}, \mathrm{Cr}, \mathrm{Cu}, \mathrm{Ni}, \mathrm{As}, \mathrm{Pb}$, and $\mathrm{Zn}$ ) and other toxic substances. As for the existing treatment methods, MBR is proved to be effective, especially in removing low biodegradable pharmaceutical compounds whereas CW can be considered as a relatively low-cost option but requires large space for treatment. Apart from membrane filtration technologies, Barakat (2010) reported the effectiveness of employing new adsorbents in treating heavy metal-contaminated wastewater. Especially, the use of biological material (e.g., bacteria, algae, yeasts, fungi or natural agricultural by-products) as biosorbent has received a great deal of interest because of the higher removal efficiency and relatively lower cost, compared to conventional methods such as precipitation and ion exchange (Wang and Chen 2009).

2) Capture of treatment side- or by-products. Green technologies that collect treatment byproducts (e.g., biogas, heat, steam and biosolids) and convert them into resources for local use would be an essential part of wastewater treatment systems (Tyagi et al. 2009; Khanal et al. 2010; Struck 2012). Presently, some wastewater treatment facilities have already incorporated anaerobic digesters, where energy-rich waste materials and biosolids (e.g., fats, oils, grease, food scraps, yard trimmings, applicable construction and/or destruction debris) can be converted into biogas, a methane-rich byproduct that is usable for energy generation. If additional organic waste streams are diverted to these facilities (e.g., food waste from landfills), even greater efficiencies and energy potential can be attained. Co-digestion technology has 
at least three times the methane production potential (e.g., biogas) of biosolids and manure. Remarkably, anaerobic digesters lead to environmental benefits from methane capture, greenhouse gas reduction, renewable energy generation, and organic waste volume reduction (Khanal et al. 2010). Other benefits include reduced operational costs associated with energy consumption, waste disposal, and existing infrastructure and expertise savings as well as economic benefits and opportunities from processing additional waste streams. To harness the energy contained in biogas, the gas can be cleaned, compressed and burned in a boiler, generating heat for maintaining digester temperatures and onsite heating. The produced biogas can also be used as a source of energy similar to natural gas and applied to maintain facility temperatures, pumps, electrical systems, and other energy needs. The excess methane can be captured and supplied to local power companies for external purposes. In California, US, there are almost 140 wastewater treatment facilities that utilize anaerobic digesters, with an estimated excess capacity of 15-30\% (US EPA, 2013). Besides, Lofrano (2012) pointed out the application of chemically assisted primary sedimentation, which consists of adding chemicals such as chitosan and other organic coagulants to increase the coagulation, flocculation and sedimentation of raw wastewater. This can contribute to increased sludge and biogas production and then reduced energy consumption.

Additionally, combined heat and power (CHP) systems, of which the concept is to use a single fuel for the production of electricity and heat and recover the waste heat from electricity generation for productive use, have received considerable attention. The five typically-considered CHP types are: gas turbines, microturbines, steam turbines, reciprocating engines and fuel cells, each with different benefits and challenges (Wong et al. 2015). CHP system can be operated in conjunction with anaerobic digesters to accomplish optimal performance. Moreover, if incineration is used, insulators and heat collectors could also be employed to capture heat/stream to convert to energy (Wong 2011). Furthermore, nutrient recovery can be gained through the beneficial reuse of biosolids in sludge treatment processes of WWTP. When properly treated, biosolids can be rich soil conditioners that contain essential nutrients (nitrogen and phosphorous, trace minerals, carbon, etc.) and provide a significant enhancement in soil water-holding capacity. These qualities can significantly improve crop growth and yields, reduce the use of chemical fertilizers, and allow communities to balance needs for sanitation and public health protection with environmentally sound methods (WERF 2010).

3) Optimization of processes in WWTP. To arrive at a sustainable utility, it is indispensable to look for strategies where water management and energy use are assessed jointly. Hence, a number of considerations should be integrated into the design and planning processes. Several studies have evaluated competing influential factors, with a focus on environmental influences. For example, Ortiz et al. (2007) used a processed-based Life Cycle Assessment (LCA) in comparing four wastewater treatment scenarios, including Conventional Activated Sludge System (CAS), CASUF, external MBR and immersed MBR. The construction, operation and dismantlement phases of the plant were considered in the system boundary, and the 
airborne emissions were of prime concern. The results indicated an overall lower environmental impact in CAS, followed by immersed MBR and external MBR. Additionally, when combining the treatment technologies with electricity production models, CAS with hydroelectric consumption model demonstrated the lowest impact as renewable energies are much more environmental friendly in electricity production compared with fossil fuels and nuclear resources. Furthermore, CAS produced high effluent quality, which not only allowed the water to be safely reused in irrigation but also enabled other applications such as groundwater recharge, household, and industrial uses. Thus, considering both environmental impact and water quality, immersed MBR coupled with the renewable energy consumption pattern was optimal. Nevertheless, this study did not take into account the environmental impacts on soil and water nor consider the toxic and health effects.

Moreover, Zhang et al. (2010) have adopted a hybrid LCA model to measure the life cycle benefit of treated water reuse in industrial and domestic applications as well as the corresponding life cycle energy consumption in the construction, operation and demolishment phases of the WWTP in Xi'an, China. The study quantified environmental impacts of different treatment stages as equivalent energy consumption. It indicated that energy consumption in operating tertiary treatment $\left(2065.28 \times 10^{9} \mathrm{~kJ}\right)$ can be significantly compensated by life cycle benefit of water reuse in terms of reduced wastewater discharge $\left(74.2 \times 10^{9} \mathrm{~kJ}\right)$ and freshwater saving $\left(1598.4 \times 10^{9} \mathrm{~kJ}\right)$. Although this study successfully linked the life cycle energy consumption with direct benefits of recycled water reuse (e.g., wastewater reduction and freshwater saving), other indirect benefits such as ecosystem protection and water cycle improvement were not considered (Chen et al. 2012).

4) Localized and networked treatment systems. The emerging use of localized treated nodes interlinked into a network allows water to be stored and used close to its source. It also increases the community's ability to respond to changes in demand and supply, improves capital efficiency and disaster resiliency, reduces impacts on natural systems, and has the potential to complement and be enhanced by the growing use of onsite energy generation systems (Slaughter 2010).

Regarding the water distribution, consumption and disposal systems, a principle target is to improve the water efficiency while minimize unnecessary water losses. For distribution systems, measures can be good solutions in increasing economic efficiency but lowering energy and resource demand, such as: i) decentralized treatment and distribution centers; ii) extended asset life through the adoption of new technology; iii) conversion of distribution systems into intelligent networks; and iv) development of smart inexpensive monitoring of asset condition. When it comes to consumption systems, the green technological opportunities exist in the exploitation of new recycled water end uses, adoption of water and energy efficient appliances, adjustment of water prices and improvement of water efficiency, etc. 
Particularly, to enhance the water and energy efficiency, in Australia, the state of New South Wales (NSW) has introduced the building sustainability index (BASIX) scheme for residential buildings. BASIX mandates that the amount of water consumed in most new residential dwelling should be $40 \%$ less than that of an average residential dwelling. The initial energy target for BASIX was set at a $25 \%$ reduction in greenhouse gas emissions compared to an average dwelling. In 2006, the energy target increased to $40 \%$ for most new homes. The regulations have forced the increasing considerations on dual flush toilets, water saving and flow regulation devices in shower heads, washing machines and dishwashers in many households. Similarly, in Western Australia, it is imperative to use pool covers for new pools and spas under the Smart Approved WaterMark scheme (AWA 2012). The strengths of these different aspects for water sustainability are discussed in Table 1.6 in detail.

Furthermore, since water drainage and disposal systems (e.g., open drainage corridors, wetlands and small ponds) are becoming more visible in the urban environment, the prime green development objectives are to optimize the design of sustainable drainage facilities, minimize effluent volumes transported to treatment plants and target releases as environmental flows. In addition, many of the storage systems can potentially offer locations for urban rooftop or similar gardens, creating small but centralized sources of locally grown food. These systems can be operated on a more distributed fashion, where appropriate, with small systems servicing smaller areas and centralized systems serving larger urban and suburban needs (ATSE 2012; Struck 2012).

Nonetheless, a key restraint for establishment and implementation of green technologies in water sectors is that water can no longer be viewed in isolation by one institution or any one group of professionals without explicit and simultaneous consideration of other related sectors and issues. Currently, water issues have become large, complex, and interconnected with other resources like renewable energies and natural ecosystems, with development sectors like agriculture, industry, transportation and communication, and with social sectors like education, health, and rural or regional development. They are also closely related to economic, environmental, legal and political factors at local, national and international scales. Consequently, water policies and major water-related issues should be assessed, analyzed, reviewed and resolved within an overall societal and development context. Otherwise, the main objectives of sustainable water management, such as improved standard and quality of life, poverty alleviation, regional and equitable income distribution, and environmental conservation could hardly be achieved (Biswas 2004). However, current failures in managing many water systems have pushed the local areas beyond their sustainable limits. For instance, some of the schemes sought to achieve considerable environmental savings through maximized water efficiency regardless of utility, economic feasibility and geographical conditions whereas other water activities that have political or financial underpinnings might trigger the degradation of ecological habitats in the long run (Chapagain and Orr 2009). 
Table 1.6. Green technology opportunities in water consumption systems

\begin{tabular}{|c|c|c|c|c|c|}
\hline \multirow{2}{*}{$\begin{array}{l}\text { Green technology } \\
\text { opportunities }\end{array}$} & \multicolumn{5}{|c|}{ Water sustainability indicator } \\
\hline & $\begin{array}{l}\text { Lower } \\
\text { E\&R } \\
\text { demand }\end{array}$ & $\begin{array}{l}\text { Reduce } \\
\text { waste \& } \\
\text { pollutant }\end{array}$ & $\begin{array}{l}\text { Increase } \\
\text { economic } \\
\text { efficiency }\end{array}$ & $\begin{array}{l}\text { Conserve } \\
\text { natural } \\
\text { assets }\end{array}$ & $\begin{array}{l}\text { Promote } \\
\text { social } \\
\text { cohesion }\end{array}$ \\
\hline $\begin{array}{l}\text { Expand use of recycled water for } \\
\text { non-potable and potable supplies }\end{array}$ & $\sqrt{ }$ & $\sqrt{ }$ & & $\sqrt{ }$ & \\
\hline $\begin{array}{l}\text { Encourage the use of water-efficient } \\
\text { appliances (e.g., showerheads, } \\
\text { washing machines and dishwashers) }\end{array}$ & $\sqrt{ }$ & $\sqrt{ }$ & $\sqrt{ }$ & $\sqrt{ }$ & \\
\hline $\begin{array}{l}\text { Install energy-efficient water } \\
\text { appliances, especially in water } \\
\text { heating }\end{array}$ & $\sqrt{ }$ & & $\sqrt{ }$ & & \\
\hline Recovery and reuse waste heat & $\sqrt{ }$ & $\sqrt{ }$ & $\sqrt{ }$ & & \\
\hline $\begin{array}{l}\text { Embrace new technology of cost } \\
\text { effective metering of individual } \\
\text { apartments }\end{array}$ & $\sqrt{ }$ & & $\sqrt{ }$ & & \\
\hline Move to cost-reflective water pricing & $\sqrt{ }$ & & $\sqrt{ }$ & $\sqrt{ }$ & \\
\hline $\begin{array}{l}\text { Include negative externalities such as } \\
\text { pollution and environmental } \\
\text { degradation in water pricing }\end{array}$ & & $\sqrt{ }$ & $\sqrt{ }$ & $\sqrt{ }$ & $\sqrt{ }$ \\
\hline $\begin{array}{l}\text { Improve water efficiency in urban } \\
\text { irrigation techniques and industrial } \\
\text { processes }\end{array}$ & $\sqrt{ }$ & $\sqrt{ }$ & $\sqrt{ }$ & $\sqrt{ }$ & \\
\hline $\begin{array}{l}\text { Provide real-time feedback on water } \\
\text { consumption to users }\end{array}$ & $\sqrt{ }$ & & $\sqrt{ }$ & & $\sqrt{ }$ \\
\hline
\end{tabular}

$\mathrm{E} \& \mathrm{R}=$ energy \& resource. Reference: ATSE (2012).

In addition, Lambooy (2011) pointed out that some green strategies for sustainable water management that encourage the reduction of fossil fuel consumption and greenhouse gas emissions by the deployment of white biotechnology (i.e. agricultural products) can come into conflict with other environmental targets. It was shown that the increased biomass for industrial usage and biofuel production would require the use of additional land and water. For example, the manufacture of one liter of bio-ethanol requires $4 \mathrm{~L}$ of process water, whereas the growth of the necessary sugar cane calls for approximately $1000 \mathrm{~L}$. This could bring nature, food, industry and biofuels into competition. Therefore, special attention needs to be paid to the potential impact of the availability of water for industrial white biotechnology. To ensure the long-term regional development, a comprehensive and systematic assessment in water use planning is essential for determination of the trade-off among a variety of issues (e.g., ambient ecosystem, engineering feasibility, cost, energy consumption, water pricing, community attitudes, etc.). Moreover, water use guidelines and regulations towards specific end uses as well as considerable national or local reports on water quality and risk control should also be established. These actions would undoubtedly standardize the treatment level, improve the reliability and enhance the public acceptance (Chen et al. 2012). 


\subsubsection{Future Research Opportunities and Challenges}

The current and the foreseeable trends indicate that water related issues will continue to become complex and will be more and more intertwined with other sectors in the future. The main trends and future research needs are described as follows:

1) Formulation of water management policies. There is an urgent need to develop and apply appropriate policies that promote green design, supply and production, worker health and safety, and consumer protection and sustainable water management should be strengthened in the direction of holistic resource governance. Table 1.7 summarizes the key aspects of the management and administrative systems for governing and delivering water sources at different levels of society (GWP 2004).

2) Integrated water management. The integrated water management has been addressed as this approach involves explicit considerations of source separation, solids treatment, waste management, liquids treatment, etc. Surrounding factors like air, amenities, energy, solid waste, transportation and urban development would also be taken into account. This allows the capture of added aesthetic, ecological, economic, energy production and conservation, recreational, social, and other benefits in ways that have never been realized before (Struck 2012).

3) Reduction of water losses. This includes the reduced evaporation losses from reservoirs, reduced leakage from distribution systems, and more effective management of surface and groundwater reservoirs (Shamir and Howard 2012). The greater use of water and energy efficient products has also been highlighted. In Australia, by conducting the Water Efficiency Labeling and Standard scheme, it is estimated that by 2021, the domestic water consumption will be decreased by 100,000 megalitres each year. The total greenhouse gas output will be reduced by 400,000 tonnes each year, which is equivalent to taking 90,000 cars off the road. The major savings would come from showerheads, washing machines and toilets (AG 2013).

Table 1.7. Key areas for water resource governance and delivery

\begin{tabular}{ll}
\hline Water governance & Key aspects \\
\hline Management categories & \\
Water resources assessment & Understanding of different water resources and needs \\
Plans for integrated water & $\begin{array}{l}\text { Combination of development options, resource use and } \\
\text { management }\end{array}$ \\
$\begin{array}{l}\text { hemand management } \\
\text { Use of water more efficiently }\end{array}$ \\
Conflict change instruments & Encouragement of a water-oriented civil society \\
Regulatory instruments & Management of disputes and guarantee of sharing of \\
& water
\end{tabular}


Economic instruments

Information management and exchange

\section{Administrative roles}

Policies and plans

Legislative framework

Organizational framework

Financing and incentive structures

Institutional capacity building
Water value and prices for efficiency and equity

Improvement of knowledge for better water management

Set of goals for water use, protection and conservation

The rules to follow to achieve policies and goals

Forms and functions

Allocation of financial resources to meet water needs

Development of human resources

Reference: Gallego-Ayala and Juízo (2011).

4) Monitoring. High-advanced monitoring technologies such as remote sensing that provide diagnostic measurements even in data sparse regions are being used to detect changes in soil moisture, water stored in snow, river and lake levels. New sensors, algorithms and improved near-real-time estimates will be proficient in providing more accurate and efficient for controlling systems that manage floods, predict droughts and distribute water to fields and cities (Shamir and Howard 2012).

5) Point-of-use water treatment technologies. There are opportunities to advance in point-of-use water treatment technologies in conjunction with stringent water quality guidelines. These range from simple, decentralized and cluster water treatment systems for rural and peri-urban areas to RO and UV-based systems that can be used in homes, public buildings, restaurants and mass feeding establishments (Shamir and Howard 2012).

6) Assessment tools and models to support decision-making. Another focus is to provide a comprehensive means to evaluate current resource recovery technologies and identify the next markets and value added products (WERF 2010). The assessment tool should assemble data in a manner that enables water to be managed effectively and guarantee the performance of one region to be accurately compared with other regions (Young 2013). As the descriptive results are unconvincing to some extent, there is a need for a quantitative assessment with respect to technical, economic, environmental and social considerations. The adoption of Multi-Criteria Analysis (MCA) is recommended which is to investigate the tradeoffs among the selected multiple conflicting criteria and then obtain rankings of different management alternatives under certain mathematical algorithms. From the computerized MCA simulation, the least preferred management options could be quickly eliminated whereas the superior alternatives can be further discussed. This can provide a powerful guidance for sustainable water management in the long term as it is possible to suggest how much a successful strategy could benefit the decision maker in exploitation, planning, development and expansion stages of water resources. With these highly persuasive data, the public acceptability and trust on green growth principles of water applications, as well as public shared responsibilities can also be greatly improved, which in turn further accelerate the booming of 
potential water markets (Chen et al. 2014). Other improved models could be developed for supply and flooding forecasting and for chemistry and biology in rivers, water bodies, groundwater, wetlands and other ecological systems (Shamir and Howard 2012).

\subsection{Book Overview}

As the primary objective of this book is to elucidate basic scientific principles and technological advances of current green technologies for sustainable water management, this 28-chapter book is divided into three themes: I) green technologies for water and wastewater management (Chapters 2-5); II) green technologies for pollution prevention/control and remediation/restoration (Chapters 6-20); and III) green technologies toward sustainable society (Chapters 21-28).

Chapter 2 describes rainwater harvesting used to augment water supplies in urban and low populated areas in Australia. Typical water quality measurements of rainwater from various locations in terms of physical, chemical, biological and organic characteristics are explained. Potable purposes are assessed and compared against the Australian Drinking Water Guidelines (ADWG), including the influence of first flush volumes on the water quality in the rainwater tank. Moreover, treatment technology for rainwater is assessed using long term pilot scale.

Chapter 3 discusses stormwater treatment technology for water reuse, indicating stormwater for harvesting and reuse purposes should be assessed primarily for nutrients, physical properties, bacteriological properties, heavy metals, organic matter since it is more unlikely to meet these water parameters. Typical water quality measurements of stormwater from various locations in terms of physical, chemical, biological and organic characteristics are compared against reuse and drinking water

standards. Conventional technology for treating stormwater is also critically reviewed in terms of its treatment ability for reuse.

As groundwater is an important component of the global water cycle and is also a resource of vital socio-economic importance, Chapter 4 summarizes the policy for its sustainable management in a changing climate is critical, as well as modern satellite technology allowing the measurement of groundwater volumes available for water supply, irrigation and environment. The changing availability of groundwater on food security and ecosystems is examined within the framework of risk management. In addition, the risk to groundwater resources from coal mining, coal bed methane and shale gas production also poses policy challenges to sustainable resource management.

Chapter 5 discusses the concepts of district water cycle management which follows the nature's example of a hydrological water cycle. The fundamental methods for water cycle analyses are proposed based on the water budget and materials balance relationships following a series of conceptual models. For a district water 
cycle with a partially closed loop of reclaimed water, prevention of pollutants accumulation in the water cycle becomes the basic requirement of system design. This needs a selection of technologies for pollutants removal in wastewater treatment and reclamation, prevention of water quality deterioration during reclaimed water storage, and enhancement of natural purification in the water cycle. A real case is introduced in this chapter as an example of application of the district water cycle management principles. By reclaiming all collectable wastewaters in a university campus and use the reclaimed water for all non-potable water uses, the efficiency of water utilization is doubled.

Chapter 6 first introduces the concepts and major categories of green and sustainable natural wastewater treatment systems, and then focuses on a few selected systems, including lagoon treatment systems, wetlands and aquifer treatment systems as well as anaerobic treatment systems with suitable case studies being discussed. Mechanism of pollutant removal in each system is described in detail; prototypes of different systems used along with their potential problems in operation are listed. The chapter concludes with the strategies used to implement these sustainable green and nature wastewater treatment systems along with future trends and brief conclusions.

Advanced anaerobic processes integrating granular sludge are emerging technologies for efficient wastewater treatment. Chapter 7 reviews current research work encompassing salient features which include merits and limitations of anaerobic granulation. In comparison with aerobic processes, major advantages of treatment by anaerobic granular sludge systems are discussed. Energy production and assessment associated with anaerobic granulation are delineated in the perspective of waterenergy nexus. Additionally, anaerobic reactor systems integrating granular sludge for waste degradation and the prospects of anaerobic granulation are also outlined.

Chapter 8 provides a thorough discussion of the recent trends in bioconversion of sludge to value added products, namely, polyhydroxyalkanoates (PHA) production, Bacillus thuringiensis (Bt) based bio-pesticides production/formulations, vermicomposting biotechnology, and production of different enzymes. The emerging value-added products are at different levels of production, facing challenges in terms of process conditions, yield, scale-up or formulation. The wastewater sludge could be used as a potential source for isolation of microorganisms, and can be a very good carbon source of many microbial possesses that could add value to sludge by producing valuable metabolic products.

Chapter 9 offers an overview of the fundamentals and applications of anaerobic wastewater treatment processes. The features like resistance to toxicity, production of biogas, less accumulation of biomass and no requirement of aeration make the use of anaerobic microbes to remove contaminants from wastewater with an effective and industrially feasible manner. This chapter also gives an insight into the effects of various environmental/physico-chemical parameters, the different types of anaerobic treatment processes based on mode of microbial growth, the different types 
of reactors associated with anaerobic treatment processes, and the process kinetics using different kinetic models.

Constructed wetlands (CWs) are sustainable systems and they have been designed as a widely accepted technology available to deal with various kinds of wastewater for nearly 40 years. Chapter 10 provides an extensive overview of present studies about the sustainable design, operation and maintenance of CWs, including plant selection (plant adaptability, plant tolerance and pollutants removal capacity), enhancing techniques (artificial aeration, intermittent operation and CWs combination, etc.) and plant reclamation and recycling.

Chapter 11 reviews on-site technologies ranging from simple septic tank followed by land filtration to high-tech membrane-filtration systems or sophisticated yet elegant designed ecosystems, such as constructed wetlands, for treating wastewater. These processes can be made flexible to accommodate specific nutrient removal processes offering advantage both technically and economically. This chapter also describes the evolution and evaluation of onsite technologies, the factors affecting their performance and case studies of on-site wastewater treatment systems.

Chapter 12 focuses on anaerobic ammonium oxidation (Anammox), a recently identified short-cut biological method to convert ammonium nitrogen to nitrogen gas using nitrite as electron acceptor, which seems to be more promising than conventional nitrification-denitrification method in terms of its efficiency, low cost and eco-friendly nature. This Chapter presents a bibliographic review of historical developments in anammox process, the microbial physiology and growth requirements of anammox bacteria, combination of anammox with partial nitrification and/or denitrification, potential inhibitors of anammox process, reactor systems used for the cultivation of anammox bacteria and applications of anammox and its related processes to treat nitrogen rich wastewaters.

The industrialization development has delivered a number of anionic species as well as anionic metal complexes into ecosystems, which have received increasing concerns of environmental and human health risks. Chapter 13 provides the current state of research on the preparation and utilization of biomass materials as biomass based activated carbons and anion-exchange/chelating resins for removal of these anions. The adsorption as well as recovery capacities of the biomass adsorbents are also summarized. It is evident that these biomass-based adsorbents show comparable adsorption capacities for the removal of various anions as those of commercial adsorbents, making the biomass materials promising for the development of technically and economically feasible technology for removal anionic pollutants.

Chapter 14 concerns about $\mathrm{P}$ removal/ recovery from wastewater due to surface water quality deterioration and $\mathrm{P}$ rock reserves depletion. This chapter focuses on both fundamental and applied aspects of this practice using agricultural by-products based biosorbents (AWBs). Insights into adsorption and desorption mechanisms, the roles of process parameters, the adsorption performance of AWBs 
the drivers, technologies and barriers for $\mathrm{P}$ recovery, as well as the criteria for selecting potential AWBs are comprehensively discussed. Although $\mathrm{P}$ removal by AWBs has gained significant achievements, $P$ recovery using AWBs still remains a challenge due to this practice is in its initial stage of development. Despite difficulties that currently exist, enormous environmental and economic benefits make this practice a promising green technology.

Chapter 15 is about treating trace organic contaminants (TrOCs) that can impose a range of possible acute and chronic toxicity effects on living organisms including human beings. When deployed on an individual basis, even the advanced treatment processes exhibit some inherent drawbacks and do not offer a complete barrier to a broad range of TrOCs that may occur in municipal wastewater. In this connection, the concept of combined processes such as coupling of membrane bioreactor (MBR) with high retention membranes, activated carbon adsorption or advanced oxidation processes has been tested with encouraging results. This chapter demonstrates the potential benefits of combined systems having MBR at the core to treat the wide varieties of TrOCs from wastewater.

Chapter 16 principally deals with the occurrences, usages, current regulations and disposal methods of heavy metals. Four heavy metals namely arsenic, chromium, lead and mercury are chosen and their environmental and health impacts due to their pollution are discussed. Further different physico-chemical remediation technologies namely chemical precipitation, ion exchange, adsorption, membrane filtration and coagulation/flocculation are reviewed. The upcoming green remediation technologies towards the future of sustainable water management, such as biosorption, biostimulation, bioaugmentation, bioleaching, biosurfactants, bioprecipitation, vermicomposting and phytoremediation, are also appraised.

Chapter 17 highlights surfactant-based separation techniques, namely micellar enhanced ultrafiltration (MEUF), in which solubilization of organic compounds into the non-polar interior of a micelle occurs. Activated carbon fibre (ACF) has a uniform micro-pore structure, faster adsorption kinetics and a lower pressure drop compared to the conventional adsorption process. MEUF process alone can remove heavy metals to certain extent, and its efficiency is further enhanced by the integrated approach of using the adsorbent like ACF. As the MEUF process generates the surfactant-rich effluent which is a major bottleneck of this process, adsorption technology using ACF as adsorbent can be the remedial measure to overcome this problem. MEUF-ACF hybrid process can be the best alternative to combat the burning issue of heavy metals.

Chapter 18 offers an innovative solution to tackle the challenging issues of membrane fouling and high operating cost of traditional electrochemical oxidation by using electrocatalytic membrane reactor (ECMR) that integrates electrochemical oxidation and membrane separation into a single processing step. The effects of main operating parameters including current density, residence time, $\mathrm{pH}$ and temperature and their mutual interactions on the performance of the ECMR are demonstrated. In 
addition, the types of electrocatalytic membrane materials and mechanism of ECMR for wastewater treatment are comprehensively specified. Finally, this chapter describes the application of ECMR to the treatment of industrial wastewater, including oily, phenolic, and dyeing wastewater.

Chapter 19 presents the fundamentals and basic principles of water reclamation by heterogeneous photocatalysis. The effects of important operational parameters on the overall treatment efficiency of photocatalytic system are addressed in terms of photocatalyst loading, pollutant concentration, $\mathrm{pH}$ and temperature of water, dissolved oxygen and light intensity. A brief introduction into the kinetics of the photocatalytic reactions associated with the photocatalytic water treatment processes is also discussed. Photocatalytic hybrid systems and future prospects for their application and development are finally embraced.

Sewage sludge as a by-product of wastewater treatment plants has become a major concern due to its large quantity and difficult disposal. In recent decades, attempts on the recycling of it include composting, energy generating, building material producing, water treatment material manufacturing, etc. Focusing on the potential techniques for conversing sewage sludge into environmentally benign materials, Chapter 20 mainly describes the application of it in the production of sludge-based ceramic particles (SBCP) and sludge-based activated carbon (SBAC). In wastewater treatment technique, SBCP as filter media material perform better than commercial ceramic particles due to the higher porosity and larger surface area. SBAC is a highly promising adsorbent that can be widely used, and the disparity in property dependent upon both the production method and the character of the sludge itself.

Impacts of climate change and climatic variability are evident in many parts of the world and will result in significant impacts on our water resources. Chapter 21 presents a methodology based on kernel regression for downscaling General Circulation Model (GCM) output to predict precipitation under IPCC SRES scenarios. Downscaling models are developed using kernel regression approach for obtaining projections of precipitation to lake-basin scale in an arid region which is considered to be a climatically sensitive region in India. Strategies for future sustainable water supplies for mitigation and adaptation are discussed.

Chapter 22 promotes sustainable resource management based on the principle of materials flow management, especially the separation of highly concentrated partial streams (source separation) such as faeces and urine with a subsequent recycling represents a suitable approach with high resource efficiency. It describes a resource economic approach to evaluate the economic value of the wastewater borne resources as well as a model to determine the pollution dependent (conventional) treatment costs for single wastewater parameters (COD, N and P). Such a model can be used as an economic steering instrument for strengthening the implementation of green technologies by identifying their resource economic potential. 
Under an ever-increasing demand for energy supply, societies are seeking sustainable, renewable, economically viable and environmentally safe energy sources. Chapter 23 gives insight into bioenergy generated from wastewater as well as energy recovery mechanisms in wastewater treatment such as anaerobic processes for biogas production, microbial fuel cells for bio-electricity and algae cultivation for biofuel. In addition, this chapter also assesses the wastewater treatment systems with biomass utilization and biogas energy recovery acting as a net carbon sequestration process.

Chapter 24 delineates both the scientific and practical implications of obtaining sustainable green energy through fermentative biohydrogen production. Fermentative hydrogen production is one of the emerging techno-economic options for substituting the depleting fossil fuel energy sources with biofuels. Recently, the use of organic-rich wastewater for biohydrogen production has proven to be costeffective and sustainable. For sustainable development, a complete understanding on biohydrogen production is essential. Several parameters that govern the successful operation of a biohydrogen process are discussed, that includes the biochemical pathways involved in anaerobic digestion, physico-chemical, biological parameters, and biochemical processes. In addition, the different types of bioreactor configurations, their performances, rate kinetics and modeling of the biohydrogen process using data driven and process based models are comprehensively discussed.

Chapter 25 summarizes the state of the art with respect to the fundamentals of AnMBRs (including its evolutionary history, and membrane and process design), the application development of AnMBRs in domestic and industrial wastewater treatment, opportunities for biogas production and waste minimization, and membrane fouling researches. The analysis of literature demonstrates the enormous competitive advantages of AnMBRs over the other available technologies in terms of environmental and economic perspectives, but AnMBRs' commercial applications are still pending due to membrane fouling issues and other challenges. Based on this review, the future research perspectives relating to its application, membrane fouling control, methane recovery and economic feasibility are proposed.

The Onsite Wastewater Differentiable Treatment System is an ecological sanitation approach with high potential to achieve sustainable treatment and management of domestic wastewater. In this system, the treatment of toilet wastes by using the composting toilet is an essential and key process because several benefits are expected to obtain if implemented, such as conservation of fresh water, elimination of sources of pathogens from the domestic wastewater stream, recovery and recycle of nutrients contained in excreta. Chapter 26 reviews some achievements of research work to describe the decomposition process of feces and urine in the composting toilet aiming the establishment of criteria for the proper design and operation of the system. The contents covers several aspects on composting of human feces which include characterization of feces, modeling of the aerobic biodegradation process, fate of water, compost safety and criteria for the design of the composting toilet. 
Palm oil mill is one of main agro-industry in Indonesia. The primary product from palm oil mill is crude palm oil which usually not more than $25 \%$ of the fresh fruit bunches. Therefore, waste management is very important to minimize environmental risk and optimize added value from the mill. The major environmental risk of palm oil mill was caused by Palm Oil Mill Effluent (POME). Chapter 27 demonstrates successfully sustainable POME management based on zero waste approach. Through this approach, POME is observed as a resource which can be utilized to prevent environmental pollution and produce valuable materials, such as energy or organic fertilizer, simultaneously. The appropriate technology of sustainable POME management for each palm oil mill is depending on the condition of palm oil mill and plantation such as energy supply and utilization, soil characteristic of oil palm plantations, and how much the management pays attention on greenhouse gases emission reduction initiative.

Nanomaterials have been developed as high-capacity adsorbents, highefficiency nanofiltration membrane technology and high-activity catalysts et al., for pollutants removal, water treatments and purification, improvement of fuels quality, air quality control, degradation of organic pollutants, remediation of polluted soils, and pollutant sensing and detection. Chapter 28 gives a comprehensive review on nanomaterials and nanotechnologies have been widely applied in developing sustainable society, such as "green" industry, agriculture, food industry, environmental protection, and renewable energy, as well as health care, are reviewed and summarized in this chapter.

\subsection{Summary}

Sustainable water management has received great attention over the recent years due to its substantial benefits to the environment, society, and economy. Improvements in water management are likely to come from green technologies fueled by individual curiosity, dedicated effort and opportunities within a strategic program supported by national and international agencies, universities and industries. These innovations can significantly contribute to less non-renewable resource requirement, a higher level of energy and nutrient recovery, reduced carbon footprint, greenhouse gas emissions and costs, minimized water losses and enhanced removal of contaminants. Further, the application of integrated water management strategies together with holistic assessment tools that take into account of technical, environmental, social and economic issues would lead to a more robust, efficient and credible solution for prospective water market and decision making. However, the relevant policies and water use guidelines and regulations on water quality, risk control and consumption behaviors should be established and updated frequently. Besides, public communications and surveys are essential and should be primarily taken to guarantee the implementation in a cost-effective way. 


\subsection{References}

AG (Australian Government) (2013).Water Efficiency Labelling and Standards (WELS) scheme, available at http://www.waterrating.gov.au/about-wels. (Accessed on August 18, 2013).

Asano, T., Burton, F. L., Leverenz, H. L., Tsuchihashi, R., and Tchobanoglous, G. (2007). Water Reuse. New York City, NY: McGraw-Hill.

ASTM (American Society for Testing and Materials) (2010). Standard terminology used for microfiltration, ultrafiltration, nanofiltration and reverse osmosis membrane processes, American Society for Testing and Materials, West Conshohocken, PA.

ATSE (Australian academy of technological sciences and engineering) (2012). Sustainable water management-securing Australia's future in a green economy, available at http://www.atse.org.au/Documents/Publications/Reports/Water/ ATSE\%202012\%20Sustainable\%20Water\%20Management\%20REPORT.pdf (Accessed on August 18, 2013).

AWA (Australian Water Association) (2012). The case for water efficiency, available at http://www.awa.asn.au/uploadedfiles/The $\% 20$ Case $\% 20$ for $\% 20$ Water $\% 20$ Effic iency\%20Position\%20Paper.pdf. (Accessed on August 18, 2013).

Barakat, M. A. (2010). "New trends in removing heavy metals from industrial wastewater." Arabian Journal of Chemistry, 4(4), 1878-5352.

Begum, S., Rasul, M. G., and Brown, R. J. (2008). "A comparative review of stormwater treatment and reuse techniques with a new approach: Green Gull." WSEAS Transactions on environment and development, 4(11), 1002-1013.

Bhandari, A., Surampalli, R. Y., Adams, C. D., Champagne, P., Ong, S. -K., Tyagi, R. D., and Zhang, T. C. (2009). Contaminants of Emerging Environmental Concern, ASCE, Reston, Virginia, 2009.

Biswas, A. K. (2004). "Integrated water resources management: a reassessment." Water International, 29(2), 248-256.

Blecken, G. T., Zinger, Y., Deletić, A., Fletcher, T. D. and Viklander, M. (2009). "Impact of a submerged zone and a carbon source on heavy metal removal in stormwater biofilters." Ecological Engineering, 35, 769-778.

Blecken, G. T., Zinger, Y., Deletić, A., Fletcher, T. D., and Viklander, M. (2010). "Effect of retrofitting a saturated zone on the performance of biofiltration for heavy metal removal- preliminary results of a laboratory study." Proc., NOVATECH, Lyon, France.

Brown, C., Gerston, J., Colley, S., and Krishna, H. J. (2005). The Texas Manual on Rainwater Harvesting, $3^{\text {rd }}$ ed., Texas Water Development Board, Autin, Texas.

Chapagain, A. K., and Orr, S. (2009). "An improved water footprint methodology linking global consumption to local water resources: A case of Spanish tomatoes." Journal of Environmental Management, 90, 1219-28.

Chen, Z., Ngo, H. H., and Guo, W. S. (2012). "A critical review on sustainability assessment of recycled water schemes." Science of the Total Environment, 426(1), 13-31. 
Chen, Z., Ngo, H. H., and Guo, W. S. (2013). "A critical review on the end uses of recycled water." Critical Reviews in Environmental Science and Technology, 43, $1446-1516$.

Chen, Z., Ngo, H. H., Guo, W. S., Lim, R., Wang, X. C., O’ Halloran, K., Listowski, A., Corby, N. and Miechel, C. (2014). "A comprehensive framework for the assessment of new end uses in recycled water schemes." Science of the Total Environment, 470-471, 44-52.

CSIRO (Commonwealth Scientific and Industrial Research Organization) (2006). Structural treatment measures, Urban stormwater best practice environmental management guidelines, CSIRO Publishing, Collingwood, Australia.

Dabbagh, T. A. (2001). "The management of desalinated water." Desalination, 135, $7-23$.

DEC (Department of Environment and Conservation) (2006). Managing urban stormwater harvesting and reuse. ISBN 1741378753, available at http://www.environment.nsw.gov.au/resources/stormwater/managestormwatera0 6137.pdf. (Accessed on August 18, 2013).

DEP (Department of Environmental Protection) (2010). Desalination in Florida: a brief review of the technology, environmental issues and its implementation, available at http://www.dep.state.fl.us/water/docs/desalination-in-florida-report. pdf. (Accessed on September 18, 2013).

Dietz, M. E., and Clausen, J. C. (2006). "Saturation to improve pollutant retention in a rain garden.” Environmental Science \& Technology, 40, 1335-1340.

Dincer, I., and Rosen, M. A. (2005). "Thermodynamic aspects of renewables and sustainable development." Renewable and Sustainable Energy Reviews, 9, 16989.

Dong, C., Schoups, G., and van de Giesen, N. (2013). "Scenario development for water resource planning and management: A review." Technological Forecasting and Social Change, 80, 749-61.

Environmental Leader (2013). Green technology. Environmental \& energy management news, available at http://www.environmentalleader.com/category/ green-technology/. (Accessed on August 18, 2013).

Frost and Sullivan (2010). Overview of green technologies in the water and wastewater industry, available at https:/www.frost.com/sublib/display-marketinsight.do? id=193993671. (Accessed on August 18, 2013).

Gallego-Ayala, J., and Juízo, D. (2011). "Strategic implementation of integrated water resources management in Mozambique: An A'WOT analysis." Physics and Chemistry of the Earth, 36, 1103-1111.

Graham-Rowe, D. (2008). "Purifying water with nano-particles." MIT Technology Review, September 29.

Gunderson, J. (2008). "Desalination Innovations: Emerging technologies aim to lower cost barrier, open up new water resources." Water Environment and Technology, 20(9), 36-44.

GWP (Global Water Partnership) (2000). Integrated Water Resources Management, Global Water Partnership, Stockholm, Sweden. 
GWP (Global Water Partnership) (2004). Catalyzing Change: A Handbook for Developing Integrated Resources Management (IWRM) and Water Efficiency Strategies, Global Water Partnership, Stockholm, Sweden.

Khanal, S. K., Surampalli, R. Y., Zhang, T. C., Lamsal, B. P., Tyagi, R. D., and Kao, C. M. (2010). Bioenergy and Biofuel from Biowastes and Biomass. ASCE, Reston, Virginia, 2010.

Lambooy, T. (2011). “Corporate social responsibility: sustainable water use.” Journal of Cleaner Production, 19, 852-866.

Li, Y. L., Deletic, A., Alcazar, L., Bratieres, K., Fletcher, T. D., and McCarthy, D. T. (2012). "Removal of Clostridium perfringens, Escherichia coli and F-RNA coliphages by stormwater biofilters.” Ecological Engineering, 49, 137-145.

Liu, Y., Gupta, H., Springer, E., and Wagener, T. (2008). "Linking science with environmental decision making: Experiences from an integrated modeling approach to supporting sustainable water resources management." Environmental Modelling \& Software, 23, 846-58.

Lofrano, G. (2012). Green technologies for wastewater treatment-Energy recovery and emerging compounds removal, Springer Briefs in Molecular Science, Springer, Dordrecht, the Netherland.

Matt, A., and Cohen, J. (2001). Harvesting rainwater is a vital signs case study. Available at http://www.uoregon.edu/ hof/S01havestingrain/rawdata.html. (Accessed on May 12, 2015).

Midilli, A., Dincer, I., and Ay, M. (2006). "Green energy strategies for sustainable development." Energy Policy, 34, 3623-33.

Ngo, H. H., Guo, W. S., and Chen, Z. (2013). New submerged membrane bioreactors (SMBRs) for sustainable water, Advances in Industrial Biotechnology, IK International Publishing House Pvt. Ltd., New Delhi, India.

NWC (National Water Commission) (2011). The national water initiatives-securing Australia's water future: 2011 assessment, available at http://nwc.gov.au/ publications/topic/assessments/ba-2011. (Accessed on August 18, 2013).

Ortiz, M., Raluy, R. G., Serra, L., and Uche, J. (2007). "Life cycle assessment of water treatment technologies: wastewater and water-reuse in a small town." Desalination, 204, 121-131.

Pimentel, D., and Pimentel, M. (2008). Human population growth, Encyclopedia of Ecology, Elsevier, Amsterdam, the Netherlands, 1907-1912.

Pimentel, D., Whitecraft, M., Scott, Z., Zhao, L., Satkiewicz, P., Scott, T. J., Phillips, J., Szimak, D., Singh, G., Gonzalez, D. O., and Moe, T. L. (2012). "Ethics of a sustainable world population in 100 years," Encyclopedia of Applied Ethics, 2nd Ed., Elsevier, London, UK, 173-177.

Shamir, U., and Howard, C. D. D. (2012). Water management in 2050, Toward a Sustainable Water Future, ASCE, Reston, Virginia.

Slaughter, S. (2010). "Improving the sustainability of water treatment systems: opportunities for innovation." Solutions for a sustainable and desirable future, $3(1), 42-49$.

Struck, S. D. (2012). Visions of green technologies in 2050 for municipal resource management, Toward a Sustainable Water Future, ASCE, Reston, Virginia. 
Tseng, M. L., Chiu, S. F., Tan, R. R., and Siriban-Manalang, A. B. (2013). "Sustainable consumption and production for Asia: Sustainability through green design and practice." Journal of Cleaner Production, 40, 1-5.

Tyagi, R. D., Surampalli, R. Y. Yan, S., Zhang, T. C., Kao, C. M., and Lohani, B. N. (2009). Sustainable Sludge Management: Production of Value Added Products. ASCE, Reston, Virginia, 2009.

U.S. EPA (Environmental Protection Agency) (2004). Guidelines for water reuse, available at http://www.epa.gov/ord/NRMRL/pubs/625r04108/625r04108.pdf. (Accessed on August 18, 2013).

U.S. EPA (Environmental Protection Agency) (2013). Organics: anaerobic digestion co-digestion, available at http://www.epa.gov/region9/organics/ad/codigest.html. (Accessed on August 18, 2013).

Vairavamoorthy, K., Gorantiwar, S. D., and Pathirana, A. (2008). "Managing urban water supplies in developing countries-Climate change and water scarcity scenarios." Physics and Chemistry of the Earth, 33, 330-339.

Wang, J. L., and Chen, C. (2009). "Biosorbents for heavy metals removal and their future." Biotechnology Advances, 27(2), 195-226.

Weber, S., Khan, S., and Hollender, J. (2006). "Human risk assessment of organic contaminants in reclaimed wastewater used for irrigation." Desalination, 187(13), 53-64.

WERF (Water Environment Research Foundation) (2010). Nutrient recovery state of the knowledge, available at http://www.werf.org/c/2011Challenges/Nutrient Recovery.aspx. (Accessed on September 18, 2013).

Wong, S. C. (2011). Tapping the energy potential of municipal wastewater treatment: anaerobic digestion and combined heat and power in Massachusetts, available at http://www.mass.gov/eea/docs/dep/water/priorities/chp-11.pdf. (Accessed on August 18, 2013).

Wong, J. W. C., Surampalli, R. Y., Zhang, T. C., Tyagi, R. D., and Selvam, A. (2015). Sustainable Solid Waste Management. ASCE, Reston, Virginia, 2015.

Young, M. D. (2013). "Investing in water services infrastructure policies and management," Ch. 1 in Investing in Water for a Green Economy, Young, M. D., and Esau, C. (eds.), Taylor \& Francis Group, Devon, UK.

Zhang, Q. H., Wang, X. C., Xiong, J. Q., Chen, R., and Cao, B. (2010). “Application of life cycle assessment for an evaluation of wastewater treatment and reuse project-Case study of Xi'an, China." Bioresource Technology, 101, 1421-1425.

Zhang, T. C., Surampalli, R. Y., Vigneswaran, S., Tyagi, R. D., Ong, S. L. and Kao, C. M. (2012). Membrane Technology and Environmental Applications. ASCE, Reston, Virginia, 2012.

Zinger, Y., Blecken, G. T., Fletcher, T. D., Viklander, M., and Deletić, A. (2013). "Optimising nitrogen removal in existing stormwater biofilters: Benefits and tradeoffs of a retrofitted saturated zone.” Ecological Engineering, 51, 75-82. 